DOI https://doi.org/10.36059/978-966-397-176-6/127-146

\title{
PSYCHOLOGICAL CONTENT AND DIVERSITY OF PERFECTIONISM OF PERSONALITY
}

\section{Kononenko O. I.}

\section{INTRODUCTION}

The problem of perfectionism is relevant and timely for modern psychological knowledge. There is a growing body of research in psychological science in this area, but they are still few. In Ukraine, the problem of perfectionism has been studied relatively recently and mainly focuses on the theoretical analysis of foreign studies, whereas in foreign psychology scientific ideas about perfectionism are widely represented. We believe that psychological studies of perfectionism are of particular importance in the genetic context (the study of the peculiarities of the formation of the personality of the perfectionist at different stages of ontogeny - in preschool, adolescent and adolescent age), in the study of extreme behaviors, in understanding the causes and factors of association. Timely identification of the perfectionist orientation of the person can prevent the development of depression, suicidal manifestations, etc. Thus, the problem of perfectionism and the timely detection of its pathological forms are of theoretical and practical importance and needs further study.

The first ideas similar to perfectionism were present in philosophy in the form of theories of the «ideal man». In the Western psychological tradition, the theme of perfectionism was regarded mainly as «the desire for perfection», and in the works of domestic scientists as a problem «ideals of personality".

The study of the phenomenon of perfectionism is associated with such names as D. Barnes, P. Gevitt, D. Johnson, J. Ashby, M. Mobley, V. Parker, K. Rice, R.Slen, H., Stampf, J., Trippy, R., Frost, and G. Flett. In recent decades, the traditional notion of perfectionism as a negative phenomenon has been replaced (P.Hweitt, G. Flett, S. Blatt, B. Kerr, S. Peters, J. de Lise, R. Freeman, D. Burns, M. Adderholt- Elliot, 
B. Clark, S. Conarton) came up with a typological approach that suggested the selection of «normal» and «pathological» types of perfectionism (K. Debrovski, T. Piechovsky, S. Peters, etc. $)^{1}$. By P. Hweitt, G. Flett, S. Ingrem, et al. incorrect correlation of perfectionist tendencies, disproportionality of the development of substructures of perfectionism as a holistic trait is a risk factor for the formation of negative consequences of perfectionism: in «normal» perfectionism, a person feels pleasure from his own perseverance, desire for self-development and improvement of personality, The «neurotic» perfectionist of this limit does not have, which leads to mental and sometimes physical self-destruction ${ }^{2}$.

The complexity of perfectionism as a concept used to describe the desire of the individual for self-improvement, lies in its global nature, since this influence can cover all spheres of personality, touching any, even intimate aspects of life.

Perfectionism as a desire to follow excessively high standards is seen as a multidimensional personal construct, but the question of its internal psychological structure remains open and debatable in science. Refinement of the structure of perfectionism will highlight important areas of corrective and preventive work. The complexity of using this theoretical construct is also due to the fact that the vast majority of studies are presented in foreign sources, the domestic scientific space does not have a sufficient number of independent and systematic studies of various aspects of personality perfectionism and its possible consequences.

\section{Psychological predictors of personality perfectionist attitudes}

Perfectionism is the desire of the individual to be perfect, perfect in everything. The main methodological obstacle to the conceptualization of perfectionism in the context of general psychological knowledge is the lack of a theoretical model, in which it is possible to represent the different facets of this phenomenon in a single continuum, determined by

1 Кононенко О.І. Перфекціонізм особистості. Одеса: Одеський національний університет імені I.I. Мечникова, 2016. 357 с.

2 Ясная В.А., Ениколопов С.Е. Перфекционизм: история изучения и современное состояние проблемы. Вопросы психологии. 2007. № 4. С. 157 - 167. 
the need to study and take into account those changes that undergo basic characteristics.. The analysis of scientific publications devoted to the study of perfectionist attitudes of the personality showed different interpretations of the central concept.

The term «predictor» (from the English verb predict - «predict, predict») can be represented in two ways: in the «broad» and «narrow» meaning of the word. In the «broad» sense, this is the initial characteristic of the individual and his environment, by which it is possible to predict with greater or lesser basis another (purpose) characteristic of the same individual. In the narrow sense of the term, predictors are called independent variables whose changes lead to the inversion of other dependent variables. We use the term "predictor» to refer to the most significant, significant psychological traits that provide the most accurate prediction of perfectionist attitudes of the individual. The complexity and ambiguity of the problem under study is that the predictor of perfectionism may not necessarily be its cause.

Among all the facets of self, highlighted by D.O. Leontiev (physical, social-role, psychological, existential and semantic), the fifth facet of self is self-conception, or the meaning of self is the most integrated and closest to the psychological mechanisms of perfectionism. This face of Self contains self-esteem (general positive or negative attitude towards oneself), self-esteem (attitude towards oneself, caused by any real merits or disadvantages) and self-acceptance (direct emotional attitude to oneself, independent of whether the subject features that explain this attitude). All these features of self-imposed make a huge impact on the whole life of a person, formed by parental education. The main goal for a person can be to maintain a positive self-esteem or to avoid a negative one at all costs. In this case, self-esteem ceases to reflect the state of real life processes and obscures the world from a person, and sometimes distorts it if the true picture of the world threatens its self-esteem ${ }^{3}$.

I.M. Borisova emphasizes the special role for the social functioning of the individual of different degrees of self-actualization in combination with the level of anxiety. In our view, the combination of self-

\footnotetext{
${ }^{3}$ Ильин Е. П. Работа и личность. Трудоголизм, перфекционизм, лень. СПб.: Питер, 2011..224 c.
} 
actualization with anxiety can be considered not only as a certain condition of its social activity, but also as an analogue of perfectionism, because in the context of the study the author considers self-actualization in a broad context, as the desire of a person to fully identify and develop their personalities and personality. The process of self-actualization - as a continuous realization by man of his potential abilities and talents, as a fuller knowledge and acceptance of his own primary nature, as a relentless thirst nation to the unity and integration of the individual.

Self-esteem as one of the possible analogues of perfectionism is important to us, first of all, by some intraspecific variables, namely:

- cognitive ability to decentration, which allows to take into account the decision-making of other people (even more socially distant from the immediate participants of the situation), which allows to reach a high level of moral consciousness and expand the scope of personal meanings to humanistic);

- personal identity, which allows to spread equal value attitude to one's self and to the object of identification, which can serve as a restraining mechanism that does not allow to devalue the object or himself in the situation of any failure.

Defining, in the wake of D.O. Leontiev, life's aspirations and selfdetermination as the feeling and realization of the freedom of man's choice of behavior and existence in the world, regardless of the forces of the external environment and the intrapersonal processes that influence him, we emphasize certain analogies with perfection.

Another predictor of perfectionism may be the persistent desire of the individual for self-improvement, which actualizes the intrinsic personality potential, sets the vector of self-development and serves a natural need.

In addition to self-improvement, basic ideals of personality that may be predictors of perfectionism include the ideals adopted by it. From what ideal, the model for imitation is chosen by the person, in many respects its destiny and life path depend. The content of ideals may change, but at some stage it sets the direction of personal development.

In our view, achievement motivation may also underlie the perfectionist personality traits, as it implies. personal readiness to exert maximum nervous and psychic and volitional efforts in order to obtain 
the best possible results in a significant sphere of activity, and therefore acts as a relevant dispositional factor in the structure of perfectionism. The motive for achievement consists of two components - the hope of success and the fear of failure. In X. Heckhausen's theory ${ }^{4}$, these components are called evaluative dispositions. Failure (as a situation of failure to achieve the intended purpose) stimulates a special condition «fear of failure». In the situation of success, "hope for success" is activated. As expressed in the structure of the motive for achieving the component of hope or fear, there are two types of people: a person who "avoids failure" is more focused on the possibility and likelihood of failure, and a person who "hopes for success" - on the likelihood of success.

At first glance, individuals with pronounced perfectionism appear to be «motivated to succeed»: the pursuit of success, impeccable performance, perfection form the very «core» of this psychological phenomenon: that high standards and aspirations are an important component of the multidimensional construct of «perfectionism»addressed "perfectionism The results of these studies indicate that individuals with high levels of perfectionism At the same time, we believe that another component of the motive for achievement - the «fear of failure», which is given not much empirical research - is also an important driver of the formation of perfectionist personality traits: according to D. Hamachek, the activities of perfectionists they are accompanied by intense negative affect: they rarely experience the pleasure of being made (which is incompatible with the experiences of success), are very afraid of making a mistake or experiencing failure, and often do not finish the case. That is why the pathological perfectionism scientist associated with the motive of avoiding failure ${ }^{5}$.

We agree with H.G. Haranyan, which, based on the data on the independence of the components of the motive for achievement,

\footnotetext{
${ }^{4}$ Хекхаузен Х. Психология мотивации достижения. СПб.: Речь, 2001. 256 с.

${ }^{5}$ Hamachek D. Psychodynamics of normal and neurotic perfectionism. Psychology. 1978. V. 15. P. 27-33.
} 
suggested that high absolute values of both evaluative dispositions may be characteristic of persons with high levels of perfectionism ${ }^{6}$.

To understand the psychological predictors of perfectionism, it is important to understand the phenomenological indicators of the motivation to achieve: the desire to compete with oneself (selfexcellence) in achieving higher results, to experience success in meaningful activity and to avoid failure, the ability to rational goalsetting, and so on.

The scientist, revealing the nature and origins of perfectionism, relies on the concept of «conflict of achievement», proposed by $\mathrm{X}$. Heckhausen. Describing the opposition to the tendencies to «strive for success» and «avoidance of failure» (or simultaneous influence of vectors of positive and negative valence), X.Heckhausen introduced the most important concept of «conflict of evaluative dispositions» as an integral attribute of motivation to achieve.

The overestimated level of personality's aspirations as the desired level of achievement, associated with self-esteem, as one of the predictors of perfectionism, is determined by the degree of difficulty of the quiet tasks that the person has to set. For the interpretation of the level of claims as a predictor of perfectionism, its psychological definition is important, which allows us to distinguish a certain analogy of this phenomenon to the perfectionist attitudes of the individual: despite the considerable prevalence in the science of knowledge about the peculiarities of the level of claims, many different definitions have accumulated $^{7}$.

Harassment is the driving force of the individual, and they are more important than the abilities with which the person is born or which he acquires in the process of interaction with his environment. By measuring the distance between the desired and the actual level of direction achieved today, one can determine the «motivational differential». People who have a realistic level of harassment, differing in their belief in harassment can lead to extremely unrealistic, overstated

${ }^{6}$ Гаранян Н. Г., Холмогорова А. Б., Юдеева Т. Ю. Перфекционизм, депрессия, тревога. Московский психотерапевтический журнал. 2001. № 4. С. 18 - 48.

${ }^{7}$ Гуляс І.А. Психологія перфекціонізму. Чернівці: Прут, 2010. 272 с. 
or understated harassment; in behavior, this is manifested in the choice of too difficult or too easy goals, in increased anxiety, self-doubt, in the tendency to avoid situations of competition, in the non-criticality of the assessment achieved, in the error of the forecast, etc.

Another psychological phenomenon, which is the predictor of perfectionism, is the supersituative (non-adaptive) activity of the individual. Unfortunately, none of the studies on perfectionism highlighted the particular role of this phenomenon. V.A. Petrovsky considers supersituative (non-adaptive) activity as the ability of a person to rise above the level of the requirements of the situation, to set goals that are excessive in terms of the main task, overcoming external and internal limitations of activity. This theory assumes the existence of motivation, the essence of which is the very attractiveness of actions with an unresolved outcome. It is important for a person to know that the choice he or she is about to make may be related to frustration or frustration, but it does not repel but is even more stimulating to action.

According to the author, supersituative activity is one of the characteristics of individuality. Indeed, «to be individual» - means to rise above the situation, overcoming external and internal limitations in the realization of oneself as a subject. The basis of such acts is formed by its own dynamics of activity, the fund of new opportunities («I can») as a source of new incentives for action («I want»). Personality, excessive in its manifestations - acts above the threshold of situational necessity, nonadaptive. V.A. Petrovsky investigated such forms of «supersituation» as «attraction to the border» (the tendency of individuals to act near the spatial marker of the border), «unselfish risk», the conversion of noncreative activity to creative, non-pragmatic rejection of prompts, « the presumption of the existence of a solution, «etc.

Phenomenology of «supersituative activity» as a potential predictor of perfectionism can be represented by such phenomena as «transitivity,» «supersituation purpose», «supersituation motivation» and «supersituation image», which, according to V.A. Petrovsky, describe the phenomenon of going beyond the requirements, which "at the beginning" of activity or communication the individual made to himself (for our understanding of the nature of perfectionism it is important that these requirements can be made by others, the important thing here is 
that the subject proceeds from them as his own). Supersituational motivation is characterized by motives that are excessive in terms of the need that initially triggered the behavior and may be sometimes at odds with that need. Supsituative goal - a goal whose adoption does not follow directly from the requirements of the situation, but the implementation of which involves the actual possibility of achieving the initial goal ${ }^{8}$.

In our view, another predictor of the formation of perfectionist attitudes of personality may be rigidity, which in psychology refers to the inability of the individual to change, the unwillingness to follow the changes that occur under the influence of circumstances, in a previously planned pattern of behavior. To understand the internal mechanisms of the emergence of perfectionist attitudes of the personality, all three types of rigidity are important predictors: cognitive (when a person, after receiving additional information, is unable to construct a new picture of the surrounding world, because it contradicts the concepts previously formed), motivational (expressing unpreparedness) abandon some needs and ways to meet them, unwillingness to accept new motives) and affective (inability to relate certain events of life to the corresponding affective reactions Thus, a person with affective rigidity is too fixed on objects to have difficulty in emotional learning).

The rigid personality does not know how and does not want to depart from stereotypes, she is very pleased to change her point of view to the unusual and original, the cause of such rigidity lies in the fact that the individual learns new knowledge through ideas coming from authoritative sources, and not through his own sensory experience. An undoubtedly positive feature of a rigid personality is its resilience to stressful situations, which is caused by less tendency to external influence, as well as special protective mechanisms. In relationships with others, rigidity is manifested by a sense of rivalry. Some traits, such as an obsession with a certain idea, an inclination to plan actions, and the ability to instill confidence in others, help shape leadership.

8 Петровский В.А. Психология неадаптивной активности. М. : ТОО «Горбунок», 1992. $224 \mathrm{c}$. 


\section{The variety of types of personality perfectionism}

As shown by the analysis of scientific literature on the subject, perfectionism is a complex phenomenon associated with both normal and neurotic (non-adaptive) functioning of the individual. This semantic ambiguity is related to the fact that in itself the desire of a person to perform his or her functional duties at a high level, to strive for success and to achieve it in different areas of his life cannot be regarded as pathological, since a well-executed work brings a sense of satisfaction, supports positive self-esteem and self-perception.

In psychological science, several hypotheses are put forward to explain the differences in the types of perfectionism. According to the first (and others), high standards do not lead to pathological consequences, if in the desire to meet them people are able to feel pleasure from the work done and do not consider the mistakes made as a complete failure. According to the second hypothesis the ability of the individual is important ${ }^{9}$.

Analysis of foreign and domestic studies on the problems of perfectionism, allowed us to formulate the basic provisions of the concept of perfectionism, which, in our opinion, most fully and comprehensively characterize this complex and ambiguous phenomenon.

The leading criterion for creating the concept of perfectionism is the multidimensionality of its psychological structure. On this basis, we approach perfectionism as a psychological property, which in the structure of personality possesses relative functional and structural autonomy and is expressed in the desire of the subject to be perfect, perfect anywhere and in anything. An important theoretical thesis of our conceptual approach to perfectionism is that the pursuit of high standards is not in itself pathological: the individual can enjoy the hard work, the desire for self-development, self-improvement, improvement of the results of work, and he accepts for himself the fact of having a boundary self- improvement. In this context, success brings pleasure to the perfectionist, nullifies his or her self-esteem, or maintains it at the proper level.

9 Ясная В.А., Ениколопов С.Е. Перфекционизм: история изучения и современное состояние проблемы. Вопросы психологии. 2007. №4. С. 157 - 167. 
Neurotic forms of perfectionism arise with an inadequate correlation of perfectionist tendencies or their disproportionate development.

All this allowed us to distinguish two types of perfectionism: global and partial, which reflect the degree of immersion of the personality in perfectionist attitudes. Each of these types of perfectionism is a complex, systematically organized psychological phenomenon, and reflects its composition, structure, and functions (by which we understand the relation between environment or subjective space and the investigated characteristic). Denmark's approach allows us to view perfectionism as the unity of differentiation and integration processes.

Thus, global perfectionism is divided into authentic, compensatory, and neurotic; and partial - to interpersonal, addictive and perfectionism.

Let us dwell on each of these species.

Global perfectionism (represented in various spheres of personal activity).

- Authentic perfectionism.

Personality with signs of global authentic perfectionism is aware of their experiences and feelings and is able to live and adequately (without distortions) express them in communication with others. Some authors (for example, K. Rogers and others) identify authenticity with aspects such as congruence (the ability to realize and experience one's emotional experience) and transparency (the ability to express and express that experience in communication). Based on the ideas of K. Rogers, we can assume that global authentic perfectionism can manifest itself in communication as a person's ability to abandon different social roles, allowing to manifest true, inherent only to her thoughts, emotions and behavior $^{10}$.

The manifestation of authentic perfectionism can be lonely if one does not integrate one's experience and experience into one's life process. Conversely, global authentic personality perfectionism leads a person to greater authenticity «through life» - but at the same time makes it less free. The analogue of global authentic perfectionism is the phrase «faithfulness to self» or «Healthy perfectionism» (D. Hamachek): thanks to authentic attitudes in perfectionism, the person opens for

\footnotetext{
${ }^{10}$ Rogers K.R., Dymond R.F. Psychotherapy and personality change. Chicago, 1954. 344 p.
} 
himself the possibility of accepting a person's own feelings, awareness of the right to feel, to feel, to feel, to feel being. Formation of authentic perfectionism is carried out in several stages:

1) awareness of one's own feelings as an objective category.

2) Acquiring self-confidence, inner consistency with one's feelings (the subject believes that his inner world gives him more authentic thoughts than external authorities). It is important that an authentic perfectionist considers any external authority alienated, imaginary, unless trust is backed up by his or her internal consent, since one can only trust oneself.

3) Acquisition of decision-making (an authentic perfectionist continually correlates possible actions with his or her own voice, otherwise the decision made may be incorrect because the right decision is an internally justified decision).

4) The ability to act even in situations where «inner obviousness» ceases to be obvious (this is a kind of «retrospective» self-confidence that allows one to act on one's own will, listening to doubts but not following them blindly).

But in spite of such differentiation, authentic perfectionism is not just a sequence of certain stages, but a property of holistic being, which includes in a collapsed form all these stages, as specific «existential abilities», which are formed ontogeny separately but subsequently integrate, forming, which becomes the main quality of being an authentic perfectionist.

It is important that global authentic perfectionism is associated not only with the experience but also with the realization of the human being in an inextricable connection with the outside world, which can be regarded as some stable internal position, through which one can contact the outside world by accepting and transforming his.

Drawing on D. Hamacek's scientific achievements, it can be emphasized that authentic perfectionists are inspired by the hope of success, easily take up business, take into account both their own resources and limitations, set realistic goals that allow them to enjoy their own strength, improve the quality of their activities. and achieve an excellent result. In the course of the work of the currant may feel a slight degree of excitement and excitement; their focus is on their own 
resources and on ways to properly accomplish the task, able to feel the deep satisfaction they have achieved and, on that basis, to increase their self-esteem. The pursuit and achievement of reasonable goals enables the authentic perfectionist to be emotionally involved in the activity, to improve the quality of work, to achieve high quality results, to enjoy the joy and satisfaction of a good work done.

Authentic perfectionism implies high personal standards, intrinsic motivation for self-improvement, a tendency to focus on purpose, a tendency to set complex goals and a willingness to strive to achieve them; implies increased self-criticism, developed self-discipline, selfcontrol, and a tendency to reflect. The expressiveness of this component of perfectionism implies self-criticism, which when overexpressed can turn into a tendency to over-self-exploration, self-digression and selfblame, which makes it impossible to accept one's own faults, shortcomings and failures. Authentic perfectionism is a component that, according to G. Flett and P.Hewitt, significantly outweighs others in people with a high degree of desire to be perfect, in people gifted and academically successful ${ }^{11}$.

Thus, the personality of an authentic perfectionist is characterized by: the ability to feel deep satisfaction on the basis of their own achievements, to increase their self-esteem; while performing the task with easy involvement in the activity, taking into account own resources and limitations, excitement and concentration on own resources.

- Compensatory perfectionism.

In Denmark, the form of perfectionism is one of the most difficult in terms of the formation of mechanisms of behavior of the subject, because maintaining a certain level of «reliability» of the individual as a whole and its individual components is the essence of complex and diverse processes of compensation. In our view, in general, compensation as a protective mechanism of the psyche is an important foundation of perfectionism, because it is based on unconscious attempts to overcome real or imagined shortcomings. The globality of compensatory

\footnotetext{
${ }^{11}$ Hewitt P.L., Flett G.L. Dimensions of perfectionism in unipolar depression. Journal of Abnormal Psychology. 1991. V. 100. P. 98-101.
} 
perfectionism is confirmed by the basic ideas of A. Adler, who viewed compensation as a vital strategy of the individual.

The desire for excellence and perfection in the compensatory perfectionist, flowing from feelings of inferiority, is combined with social interest, that is, the pursuit of perfection in anything should be socially positive, include the desire for the well-being of all people, but possible and opposite, when personal development is possible. social interest is not expressed enough, it is selfish, it strives for personal superiority and domination over others, absorbed by its own interests and self-protection. Exaggeration of a healthy desire to constantly overcome feelings of inferiority can be transformed into a complex of inferiority an obsessive tendency to exaggerate their physical or intellectual abilities at times because of inadequate actions, devoid of social interest (constant demonstration of their competence, tendency to compete, habit.

Individual differences in the manifestations of compensatory perfectionism can be identified by drawing on A. Adler's two variables:

- The presence or absence of social interest,

- Presence or absence of high or low level of vital activity.

Based on these two variables, A. Adler identified the following types of personalities that can be extrapolated to the typologization of perfectionism we propose:

- manager (high activity, but low social interest);

- taker (not very high activity, low social interest);

Avoiding (low activity, low social interest);

- socially useful type (high activity is combined with high social interest).

Compensatory perfectionism may differ in form: it may be either socially acceptable or not; direct (an attempt to succeed in an area where a deficiency is felt) and indirect distinguish the following form of perfectionist behavior: obsessive re-examinations of their own activities, a compulsive search for support and approval from others, a constant desire to correct others, or excessively deliberate before making a decision; R. Frost, A. Turcotte, R. Heinberg, J. Mattia, et al. There is an alternative behavior - procrastination of the beginning of activity or 
avoidance, since the end result already appears unsatisfactory at the beginning of work ${ }^{12}$.

- Neurotic perfectionism.

The behavior of a neurotic perfectionist is driven by the fear of failure. Fearful of possible mistakes and failures, people with a neurotic desire for excellence often cannot get started and postpone it (i.e., have a pronounced procrastination). Guided by too high expectations of themselves, they are constantly experiencing anxiety, shame and guilt. In the course of their work, their attention is focused on their own shortcomings and thoughts about a possible mistake. They are deprived of the pleasure of being done, even if the work is objectively done well. S. Blat also believes that «neurotic» perfectionism stems from the desire to avoid failure [556]. Deep-rooted feelings of inferiority and vulnerability plunge people into an endless collective of self-destructive endeavors, and any business or task becomes another threatening challenge.

G. Flett, K. Blankstein, S. Mosher and R. Davis also confirmed that high standards combined with prohibition of error and failure may motivate destructive behavioral strategies. Thus, pathological perfectionism is interconnected with a number of maladaptive characteristics: irrational thinking, inclination to self-criticism, selfblame and blame of others, procrastination, low efficiency in professional career, non-adaptive educational motivation, lowered problem search, reduced coping strategies, emotional maladaptation, low self-esteem, high risk of suicidal behavior ${ }^{13}$.

Considering perfectionism as a negative phenomenon, D. D. Burns describes perfectionists as people who demonstrate an obsessive, unwavering pursuit of impossible, unattainable goals and evaluate themselves depending on their achievements, «measuring», determining their value by productivity, success. A.R.Pacht also gives a negative assessment of perfectionism as the pursuit of non-existent perfection,

\footnotetext{
${ }^{12}$ Frost R., Marten P., Lahart C. The dimensions of perfectionism.Cogn. Ther. Res. 1990. V. 14. P. 449-468.

${ }^{13}$ Flett G.L., Hewitt R.L., Blankstein K.R., Koledin S. Dimensions of perfectionism and irrational thinking. Journal of Rational-Emotive \& Cognitive-Behavior Therapy. 1991. № 9 (3). P. 185-201.
} 
which constantly keeps a person in suspense and anxiety. Neurotic perfectionism is associated with a variety of personality problems and psychosomatic manifestations: migraines, depression, anorexia and bulimia, suicide attempts, and the like.

Studies by M. A Adderholt-Elliot also confirmed the neurotic manifestations of the perfectionist personality: slowness, fear of failure, tendency to be guided by the principle of «all or nothing», indecision, fear of action, workaholic. The fear of perfectionists to be imperfect though in some ways, the fear of admitting a blunder, is associated with various negative experiences and increases the slowness.

Describing the personality of a neurotic perfectionist, S. Blatt wrote that their sense of inferiority and vulnerability is a profound formation; it immerses a person in an endless cycle of self-destruction, in which any task or the start of something new becomes another threatening challenge. The main problem of the neurotic perfectionist is that no effort is ever sufficient, as he constantly seeks approval and acceptance, persistently tries to avoid mistakes and failures, and any circumstances that affect self-esteem generate intense negative affect.

Describing the neurotic aspects of perfectionism, N.G. Garanyan emphasizes too high standards and aspirations, distorted social cognition (perceiving other people as delegating high expectations, ,compulsion for excellence"), Perfectionism (permanent comparison of oneself with other people at the pole of the most successful, ,life in comparison mode"), negative selection (selective concentration on failures and mistakes), polarized thinking (dichotomous evaluation result), symptoms of depression, $t$ anxieties, fear of failure, high social anxiety, intense daily stress, the picture of «inadequate level of harassment», defensive tactics of avoiding failure (alternating the election of too difficult and very easy goals), «over-mobilization» of copy-resources with the prevalence of avoiding coping-strategies, social avoidance.

Therefore, the main characteristics of a person with neurotic perfectionism are: permanent dissatisfaction with the done (the result never seems sufficient), very high expectations are presented, the main motive of behavior - fear of failure, tendency to experience strong anxiety, shame, guilt; the tendency to avoid (focusing on one's own shortcomings and thinking about how to avoid mistakes). 
- Partial perfectionism (interpersonal, addictive, experfectionism).

In psychology and psychiatry, the term «partiality» is widely used to characterize the uneven development of certain components of mental activity. One of the first problems of partiality concerned B.M. Teplov, who suggested that along with the general typological properties that characterize the nervous system as a whole, there are temporary (partial) mental properties. Later, the problem of partiality was formulated by V.D. Nebilicin, who defined it as a mismatch between the results of measurements of the same properties when determining them in different regions, zones and divisions of the cerebral hemispheres.

In the context of our study, by partiality we mean the phenomenon, which is expressed in the inconsistency of the expressiveness of certain psychological properties of perfectionism in different spheres of personality activity. Accordingly, the particularity of perfectionism can affect others, the reference environment, and the world at large.

- interpersonal partial perfectionism, primarily aimed at other people, implies increased demands on them, and sometimes unrealistically high standards, expectations of human perfection and constant evaluation of others. According to P. Hewitt and G. Flett, these beliefs and expectations regarding the abilities of other people mainly relate to significant people from close range. According to the authors, such a demanding perfectionist gives rise to frequent accusations against other people, a lack of trust and feelings of hostility towards people.

K. Horney described the inclination of perfectionists to expect impeccability in the behavior of others, a low tolerance for their mistakes and failures ${ }^{14}$. She emphasized their peculiar perception of the social world as threatening, represented by people, prone to harsh appraisals and instant frustrations when performing other activities at a level lower than perfect. In our view, when describing interpersonal perfectionism, some important characteristics were not taken into account, such as the tendency to be jealous of others' successes and to compare themselves with them on the principle of «Other people's achievements - a testimony of my failure», since A. Adler wrote that some perfectionists $346 \mathrm{c}$.

${ }^{14}$ Хорни К. Невротическая личность нашего времени.М. : Прогресс-Универс, 1993, 
are inclined to compare oneself with their surroundings and even with the heroes of the past, and in general, persons with marked perfectionism live their lives in a «mode of comparison» with others, while experiencing a sense of their own «secondaryness and failure"15.

Addictive perfectionism reflects the need of the individual to meet the standards and expectations of significant others, which can provoke a certain psychological dependence on them. It is important that in this case the subject is guided only by high standards, only delegated to him by significant others (subjective sense of „compulsion to perfection”).

In psychology, addiction, in the broad sense, means an obsessive need experienced by a person in a particular activity, including communication, and the inability to cease this activity or relationship with significant people.

For the addictive perfectionist, such an illusion is created through psychological dependence on significant people, but such dependence is limited and ineffective, violates the natural adaptive capacity at the psychophysiological level.

This parameter of perfectionism reflects the subjective belief that other people are unrealistic in their expectations, inclined to very strictly evaluate the individual and put pressure on him to be perfect; at the same time, the individual is convinced of his or her own inability to please others and is psychologically dependent on them. The importance of this parameter is confirmed by studies of psychosocial predictors of depression within the concept of „emotional expressiveness”. These studies have shown that the risk of recurrence of depression is very high if the subject perceives her husband or wife as very critical. It was supposed that this perfectionism can have many adverse effects in the form of anger, fear of negative evaluation, increased importance of other people's attention and approval.

Few scientific studies have revealed the effect of perfectionism on intimate relationships with other, non-referential individuals/ Persons with high rates of «addressed to others» and «socially - offered» perfectionism showed low levels of sexual satisfaction. «I-addressed»

15 Адлер А. Практика и теория индивидуальной психологии. М. : Директ-Медиа, 2008, 406 c. 
perfectionism was associated with negative coping style and marital stress in the form of increased criticality, sarcasm and vindictiveness. Subjects who have partners with high "targeting" perfectionism exhibit poorer adaptation in marriage, report more family difficulties, and experience less support from spouses than patients whose partner is not as demanding. P. Hewitt, G. Flett, and S. Mikhail concluded that in a marital relationship the ,target” of unrealistic expectations suffers, but not the perfectionist himself $\varkappa^{16}$.

- Experfectionism - aimed at the world at large. Exopsychic component is determined by the attitude of the individual to the external environment, i.e. to the whole sphere of opposing personality and to what it may in a certain way relate.

According to P. Hewitt and G. Flett, the basic psychological content of this type of perfectionism may include the conviction that everything in the world must be accurate, neat, correct, and that all human and world problems must receive a correct and timely solution. N.G. Garanyan .showed that in empirical studies it was not possible to confirm the relationship of this type of perfectionism with symptoms of depression and anxiety, i.e., the neurotic component in it is poorly expressed.

Thus, partial perfectionism touches others, the reference environment, and the world at large, and is subdivided into polysubjective, addictive, and ex-perfectionism.

\section{SUMMARY}

Thus, the main criterion for creating the concept of perfectionism is the multidimensionality of its psychological structure, which allows to approach its study as a psychological property, which in the structure of the individual has relative functional and structural autonomy and is expressed in the desire of the subject to be perfect, perfect anywhere and any in what. The desire of the individual to high standards by itself is not pathological, the individual can enjoy the hard work, the desire for self-

16 Hewitt P.L. Flett G.L., Turnbull-Donovan W., Mikail S.F. The multidimensional perfectionism scale: reliability, validity and psychometric properties in psychiatric samples.Psychological Assessment: a Journal of Consulting and Clinical Psychology. 1991. V. 3. P. 464-468. 
development, self-improvement, improvement of work results, and he accepts for himself the fact that there is a limit to personal selfimprovement. Neurotic forms of perfectionism arise with an inadequate correlation of perfectionist tendencies or their disproportionate development.

There are two types of perfectionism: global and partial, each of which is a complex, systematically organized psychological phenomenon, and reflects its composition, structure and functions (by which we mean the relation between environment or subjective space and the investigated characteristic).

\section{REFERENCES}

1. Кононенко О.I. Перфекціонізм особистості. Одеса: Одеський національний університет імені I.I. Мечникова, 2016. 357 с.

2. Hamachek D. Psychodynamics of normal and neurotic perfectionism. Psychology. 1978. V. 15. P. 27-33.

3. Ясная В.А., Ениколопов С.Е. Перфекционизм: история изучения и современное состояние проблемы. Вопросы психологии. 2007. №4. С. 157 - 167.

4. Ильин Е. П. Работа и личность. Трудоголизм, перфекционизм, лень. СПб.: Питер, 2011..224 с.

5. Хекхаузен Х. Психология мотивации достижения. СПб.:Речь, $2001.256 \mathrm{c}$.

6. Гаранян Н.Г., Холмогорова А. Б., Юдеева Т. Ю. Перфекционизм, депрессия, тревога. Московский психотерапевтический журнал. 2001. №4. С. 18 - 48.

7. Гуляс І.А. Психологія перфекціонізму. Чернівці: Прут, 2010. $272 \mathrm{c}$.

8. Петровский В.А. Психология неадаптивной активности. М. : ТОО «Горбунок», 1992. 224 с.

9. Ясная В.А., Ениколопов С.Е. Перфекционизм: история изучения и современное состояние проблемы. Вопросы психологии. 2007. №4. C. $157-167$.

10.Rogers K.R., Dymond R.F. Psychotherapy and personality change. Chicago, 1954. 344 p. 
11.Hewitt P.L., Flett G.L. Dimensions of perfectionism in unipolar depression. Journal of Abnormal Psychology. 1991. V. 100. P. 98-101.

12. Frost R., Marten P., Lahart C. The dimensions of perfectionism.Cogn. Ther. Res. 1990. V. 14. P. 449-468.

13.. Flett G.L., Hewitt R.L., Blankstein K.R., Koledin S. Dimensions of perfectionism and irrational thinking. Journal of Rational-Emotive \& Cognitive-Behavior Therapy. 1991. № 9 (3). P. 185-201.

14. Hewitt P.L. Flett G.L., Turnbull-Donovan W., Mikail S.F. The multidimensional perfectionism scale: reliability, validity and psychometric properties in psychiatric samples.Psychological Assessment: a Journal of Consulting and Clinical Psychology. 1991. V. 3. P. 464-468.

15.Хорни К. Невротическая личность нашего времени.М. : Прогресс-Универс, 1993, 346 с.

16.Адлер А. Практика и теория индивидуальной психологии. М. : Директ-Медиа, 2008, 406 с.

\section{Information about the author: Kononenko O. I.,}

Doctor of Psychological Sciences, Professor at the Department of Differential and Special Psychology, Odessa I. I. Mechnikov National University 15/13, Tenistaya str., Odessa, 65009, Ukraine 